\title{
Epidemiology and associated factors of atopic dermatitis in Malagasy children
}

\author{
F. A. Sendrasoa 1* (D, I. M. Ranaivo², N. H. Razanakoto1, M. Andrianarison', O. Raharolahy' , V. T. Ratovonjanahary', \\ M. Sata', M. F. Rakotoarisaona', L. S. Ramarozatovo' and F. Rapelanoro Rabenja'
}

\begin{abstract}
Background: Little is known about the epidemiology and associated factors of childhood AD in the markedly different, low-income, tropical environment like Madagascar.

Methods: We aim to assess the epidemiology and associated factors of AD in individuals fewer than 15 years of age in Antananarivo Madagascar. It was a retrospective and descriptive study over a period of 7 years (2010 to 2016) in children 6 months to 14 years in the Department of Dermatology, Joseph Raseta Befelatanana Antananarivo Madagascar. The diagnosis of AD was based on clinical data.

Results: The prevalence of AD was 5.6\% in children aged 6 months to 14 years. The details of 151 cases of atopic dermatitis were analyzed. The mean age of patients was 4 years. There was a female preponderance (sex ratio: 0.7). A family history of AD was noted in 56 cases (37\%). No association between breast-feeding and AD was found. The age of onset of AD was before the age of 3 months in $7.5 \%$ and between 6 months to 5 years in $70 \%$. Children born in March (dry season) had the highest risk of AD. Consultations for AD increased during the winter (from July to October; $p=0.005)$. However, the prevalence of AD was similar in urban and rural areas.
\end{abstract}

Conclusion: Weather may have an impact on the prevalence of atopic dermatitis in Madagascar. No significant correlation was found between the duration of breastfeeding and AD, as well as urbanization.

Keywords: Associated factors, Atopic dermatitis, Antananarivo Madagascar, Prevalence

\section{Introduction}

Atopic dermatitis (AD) is a chronic inflammatory skin disorder that is characterized by intense itching and recurrent eczematous lesions. AD affects up to $20 \%$ of children and $3 \%$ of adults; latest global data shows increases in its prevalence [1]. In Africa, the prevalence of $\mathrm{AD}$ ranges from $4.7 \%$ to $23 \%$. The onset of $\mathrm{AD}$ is usually between 2 and 6 months of age, although it can begin at any age [2]. It was previously thought that it resolved by adulthood in most cases, but evidence suggests that it is a chronic condition that may persist into adulthood [3].

*Correspondence: nasendrefa@yahoo.fr

${ }^{1}$ Department of Dermatology, University Hospital Joseph Raseta Befelatanana, Antananarivo, Madagascar

Full list of author information is available at the end of the article
Several factors such as environmental exposures (use of personal care products, climate exposure, pollution, food...) and genetics attribute to the increased global prevalence of $\mathrm{AD}$ in predisposed individuals [4]. We aim to describe the prevalence and factors associated of $\mathrm{AD}$ in Antananarivo Madagascar.

\section{Methods}

A cross-sectional study was conducted based on a review of medical registries in the Department of Dermatology, University Hospital Joseph Raseta Befelatanana, Antananarivo Madagascar. Patients who required healthcare services from 2010 to 2016 were included. The inclusion criteria were age $<15$ years, registered diagnosis of $\mathrm{AD}$. $\mathrm{AD}$ was diagnosed by the reference dermatologist according to the criteria of

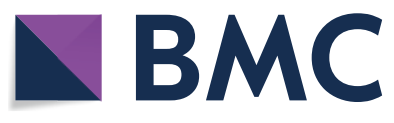

(C) The Author(s) 2019. This article is licensed under a Creative Commons Attribution 4.0 International License, which permits use, sharing, adaptation, distribution and reproduction in any medium or format, as long as you give appropriate credit to the original author(s) and the source, provide a link to the Creative Commons licence, and indicate if changes were made. The images or other third party material in this article are included in the article's Creative Commons licence, unless indicated otherwise in a credit line to the material. If material is not included in the article's Creative Commons licence and your intended use is not permitted by statutory regulation or exceeds the permitted use, you will need to obtain permission directly from the copyright holder. To view a copy of this licence, visit http://creativeco mmons.org/licenses/by/4.0/. The Creative Commons Public Domain Dedication waiver (http://creativecommons.org/publicdomain/ zero/1.0/) applies to the data made available in this article, unless otherwise stated in a credit line to the data. 
United Kingdom Working Party modified. Age, sex, birth months, age of onset, associated comorbidities, breastfeeding duration, personal and familial past medical history (particularly personal and familial atopy) were obtained. Topographical distribution of lesions and body surface area were evaluated.

All study procedures were performed in accordance with the Ethics Committee of University Hospital Joseph Raseta Befelatanana Antananarivo, Madagascar. Study participants and their parents were informed about the study procedures and written informed consent was obtained.

Data collection was made by logiciel Microsoft Excel. Statistical analyses were processed by « $\operatorname{logiciel} \mathrm{R} »$. The $\mathrm{X}^{2}$ test was used to analyze the results, and $\mathrm{p}<0.05$ was considered statistically significant.

\section{Results}

151 cases of atopic dermatitis were identified among 2665 children $<15$ years seen in the Department of Dermatology, University Hospital Joseph Raseta Befelatanana Antananarivo Madagascar from 2010 to 2016 , with the prevalence of $5.6 \%$. 80 cases (52.9\%) were $<2$ years and 71 cases were $>2$ years. The mean age of $\mathrm{AD}$ patients was 4 years. The mean age of onset was 3 years. The age of onset of AD in 104 children (69\%) was before the age of 5 years $70.22 \%$. There was a female preponderance (sex-ratio: 0.73). Distribution of participants via sociodemographic and clinical characteristics was shown in Table 1.

Children born in March (dry season) had the highest risk of $\mathrm{AD}$ (12.39\% of cases). Concerning breastfeeding, $77 \%$ of children had exclusive or partial breastfeeding for at least 12 months. No association between breast-feeding and $\mathrm{AD}$ was found in our study. The correlation between the duration of breastfeeding and AD prevalence was shown in Table $2(p=0295)$. Consultations for $\mathrm{AD}$ increased during the winter (from July to October) $(p=0.005)$. Furthermore, the prevalence of $\mathrm{AD}$ was similar in urban (developed regions where pollution is more severe) and rural areas in our study. The frequency of AD consultation according to season and to geographical origin was shown also in Table 2.

Pruritus and xerosis were present in 62.9 and $64.2 \%$ of cases, respectively. Topographical distribution by age was shown in Table 3. Photographs representing topographical distribution by age are shown in Figs. 1, 2 and 3. No association between body surface affected and pruritus was found ( $\mathrm{p}$ value $=0.482$ ).

Papulovesicular lesion was present in 101 cases (66.6\%). Impetiginized and lichenified lesions were present in 13 $(8.6 \%)$ and 4 cases $(2.64 \%)$, respectively.
Table 1 Distribution of participants via sociodemographic and clinical characteristics

\begin{tabular}{|c|c|c|}
\hline Characteristics & $\mathbf{N}$ & $\%$ \\
\hline \multicolumn{3}{|l|}{ Sex } \\
\hline Male & 64 & 42.3 \\
\hline Female & 87 & 57.6 \\
\hline \multicolumn{3}{|l|}{ Age group (years) } \\
\hline $0-2$ & 66 & 43.7 \\
\hline $2-5$ & 33 & 21.8 \\
\hline $5-10$ & 36 & 23.8 \\
\hline $10-15$ & 16 & 10.6 \\
\hline Mean age: 4 Median: 2 & Minimum: 6 months & $\begin{array}{l}\text { Maximum: } \\
14 \text { years }\end{array}$ \\
\hline \multicolumn{3}{|l|}{ Age of onset (years) } \\
\hline $0-5$ & 105 & 69.5 \\
\hline $5-10$ & 33 & 21.8 \\
\hline $10-15$ & 13 & 8,6 \\
\hline \multicolumn{3}{|l|}{ Personal atopy } \\
\hline Allergic rhinitis & 32 & 21.1 \\
\hline Food allergy & 25 & 16.5 \\
\hline Drug allergy & 2 & 1.3 \\
\hline Atopic dermatitis & 19 & 12.5 \\
\hline Asthma & 9 & 5.9 \\
\hline Allergic conjonctivitis & 5 & 3.3 \\
\hline \multicolumn{3}{|l|}{ Clinical presentation } \\
\hline $\begin{array}{l}\text { Acute lesions (papulovesicular } \\
\text { lesions) }\end{array}$ & 118 & 78.1 \\
\hline Impetiginized lesion & 13 & 8.6 \\
\hline Lichenification & 10 & 6.6 \\
\hline \multicolumn{3}{|l|}{ Body surface area (\%) } \\
\hline$<5$ & 5 & 3.3 \\
\hline $5-10$ & 6 & 3.9 \\
\hline $10-20$ & 72 & 47.6 \\
\hline$>20$ & 68 & 45 \\
\hline
\end{tabular}

Table 2 Correlation between the geographical origin, the duration of breastfeeding and the prevalence of $A D$

\begin{tabular}{lrrr}
\hline Characteristics & N & \% & p value \\
\hline $\begin{array}{l}\text { Geographical origin } \\
\text { Urban }\end{array}$ & 75 & 49.67 & 0.89 \\
Rural & 76 & 50.33 & \\
Breastfeeding duration (months) & & \\
3-6 & 116 & 76.8 & 0.295 \\
6-12 & 31 & 20.5 & \\
$>12$ mois & 4 & 2.6 & 0.005 \\
Season of consultation & & & \\
Winter (dry season: July & 78 & 51.6 & \\
$\quad$ to October) & & & \\
Summer (rainy season: & 33 & & \\
$\quad$ December to April) & & & \\
\hline
\end{tabular}


Table 3 Topographical distribution by age

\begin{tabular}{llll}
\hline Topographical distribution of AD & $\begin{array}{l}\text { Children } \\
\text { < 2 years }\end{array}$ & $\begin{array}{l}\text { Children } \\
\text { > 2 years }\end{array}$ & p value \\
\hline Convex areas of the face & 51 & 32 & 0.014 \\
Extensor surface of upper limb & 30 & 25 & 0.45 \\
Lower limb & 21 & 22 & 0.9 \\
$\begin{array}{l}\text { Skin folds (neck, large flexures of the } \\
\quad \text { elbows and knees) }\end{array}$ & 14 & 20 & 0.27 \\
$\quad$ Scalp & 9 & 2 & 0.03 \\
\hline
\end{tabular}

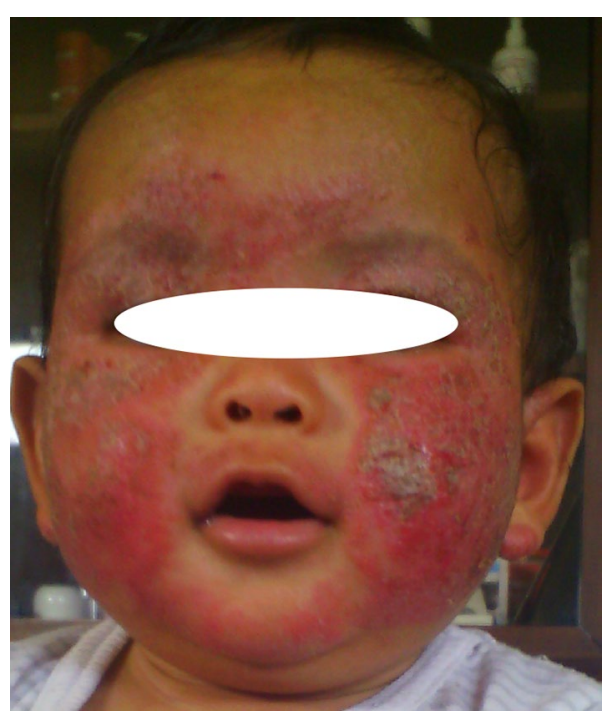

Fig. 1 Facial involvement of atopic dermatitis

A family history of atopy was noted in 71 cases (47.01\%), especially with family history AD in 56 cases (37\%). Atopic dermatitis was associated with allergic rhinitis in 33 cases $(21.8 \%)$, food allergy in 25 cases (16.5\%) and asthma in 9 cases (5.9\%).

\section{Discussion}

This study reports the recent epidemiology of $A D$ in children $<15$ years in the Department of Dermatology, University Hospital Joseph Raseta Befelatanana Antananarivo Madagascar.

Our result shows that the prevalence of $\mathrm{AD}$ in children $<15$ years $(5.6 \%)$ has been raised in recent years, much higher than that from previous study $(1.02 \%$ in a previous study in 3593 children) [5]. It is consistent with results from other studies. Atopic dermatitis in France has a prevalence of 6 to $9 \%$ before the age of 15, depending on the strictness of the criteria applied [2]. The " hygiene hypothesis " offers a potentially credible and parsimonious explanation for the increasing prevalence of atopic dermatitis noted in many westernized

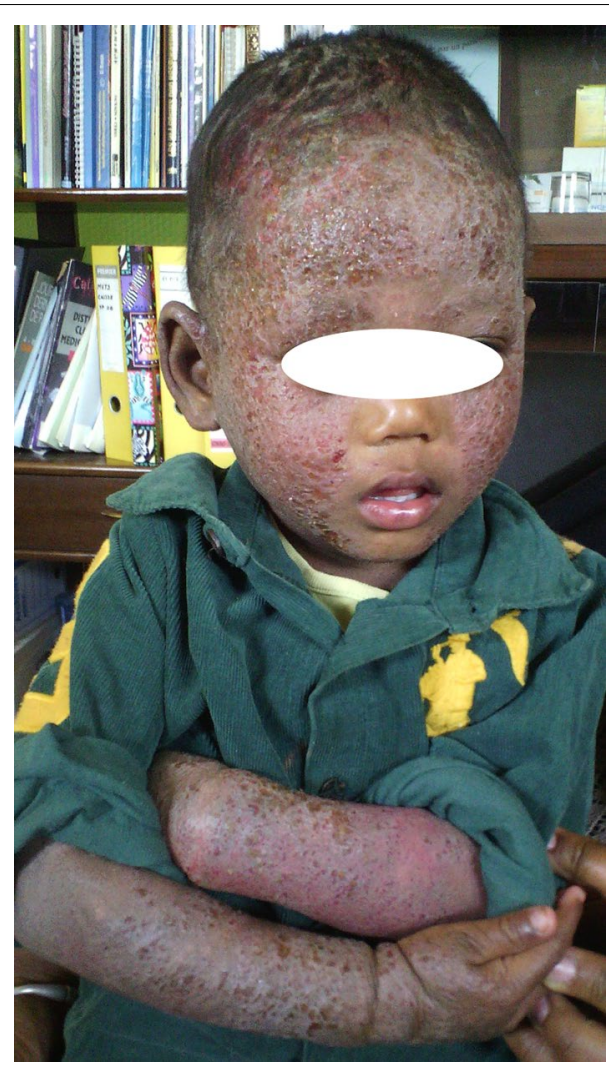

Fig. 2 Extensive atopic dermatitis

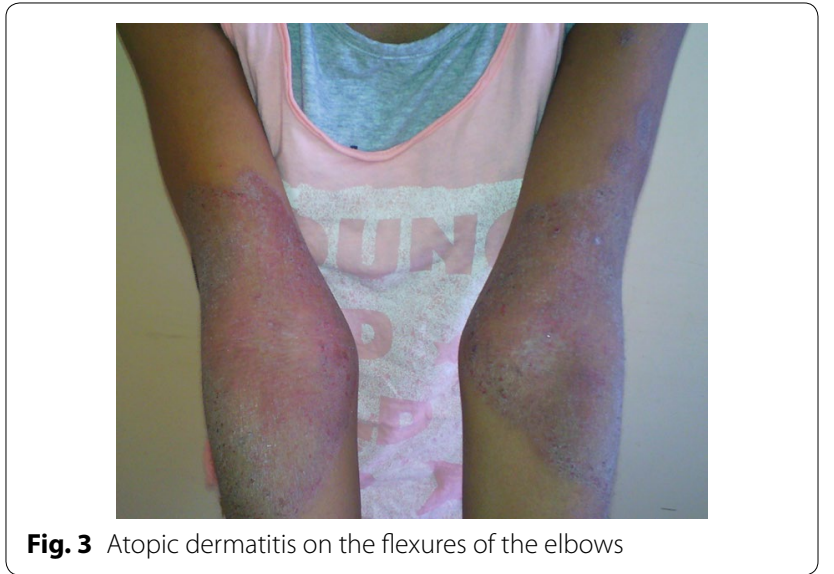

populations. The model of the hygiene theory has been clarified in recent years: environmental factors alter the diversity of skin and digestive microbiomes, and this diversity seems to play a major role in the development of atopy [6].

The results of some studies analyzing the relationship between urbanization and AD are different from ours. A Chinese study showed that the prevalence of $\mathrm{AD}$ in urban 
areas of Shanghai was gradiently and significantly higher than in rural areas (4.6\% vs $10.2 \%)$ [7]. A marked urbanrural gradient was evident also in Ethiopian population, Yemaneberhan et al. reported that lifestyle factors linked to urbanization were associated with an increased risk of AD [8]. According to Kantor R, urban living may be associated with increased stress, greater proximity to automobile traffic and related pollutants [4].

The result of our study found an increased risk of $\mathrm{AD}$ in infants born during dry season (March to September). It is consistent with findings from some studies. Taiwanese case-control study reported that children born in October, November and December had higher risk of $\mathrm{AD}$ compared with children born in May. The relative humidity in October, November and December is relatively low in Taiwan [9]. A cross-sectional report in Japanese pediatric population showed that children born in the automn (October, November and December) were more likely to have AD [10]. One study who examined the association of season of birth with DNA Methylation and allergic disease found that autumn birth increased risk of eczema, relative to spring birth [11]. A metaanalysis including 9 studies in the northern hemisphere found also that $\mathrm{AD}$ was significantly associated with fall and winter compared with spring birth [12].

Some studies reported a different effect of breastfeeding on AD. A meta-analysis found that exclusive breastfeeding for at least 4 months can reduce the incidence of AD in infants [13]. However, new evidence from a 2016 cohort study now suggests that breastfeeding itself may be a risk factor. The study proposes that the breastfeeding timeline might be crucial in determining whether it prevents or incites the development of AD in all children regardless of risk [14]. A Japanese study reported also that the duration of exclusive breastfeeding for at least 6 months were associated with the prevalence of childhood eczema in a nationwide web survey [15]. Neither development of AD in children nor the age of onset of $\mathrm{AD}$ has correlation between the duration of breastfeeding in our study; this finding is consistent with other studies.

70 children (47\%) had familial history of atopic diseases in our study. Our finding was lower than previous study reported by Wen $\mathrm{HJ}$ in which $70 \%$ of $\mathrm{AD}$ patients had a positive family history of atopic diseases [16]. Wadonda-Kabondo $\mathrm{N}$ et al. reported also that the odds of developing $\mathrm{AD}$ are 2 to threefold higher in children with one atopic parent, and this increases to three to fivefold if both parents are atopic [17]. Indeed, several genes were linked to the epidermal function and the immune system. The common loss-of-function variants within the fillagrin gene which encode the epidermal barrier protein fillagrin and their association with $\mathrm{AD}$ have important interest in the significance of skin barrier impairment in the development of AD [18]. Fillagrin determines the skin barrier integrity. Rehbinder EM et al. reported also that parental and pregnancy related factors (such as delivery $>38$ gestational weeks, paternal age $>37$ years, multiparity and maternal allergic diseases) were predictive for dry skin and AD [19].

\section{Conclusion}

The present study shows that weather may have an impact on the prevalence of atopic dermatitis in Madagascar. No significant correlation is found between the duration of breastfeeding and $\mathrm{AD}$, as well as urbanization.

\section{Acknowledgements \\ We are grateful to all participants in this study.}

\section{Authors' contributions}

FAS conceived this study and performed statistical analyses. All authors were involved in the writing of the manuscript or patient clinical care. LSR and FRR contributed to the critical revision of the manuscript. All authors read and approved the final manuscript.

Funding

No funding.

\section{Availability of data and materials Not applicable.}

\section{Ethics approval and consent to participate}

All study procedures were performed in accordance with the Ethics Committee of University Hospital Joseph Raseta Befelatanana Antananarivo, Madagascar. Study participants and their parents were informed about the study procedures and written informed consent was obtained.

\section{Consent for publication}

Not applicable.

\section{Competing interests}

The authors declare that they have no competing interests.

\section{Author details}

${ }^{1}$ Department of Dermatology, University Hospital Joseph Raseta Befelatanana, Antananarivo, Madagascar. ${ }^{2}$ Department of Dermatology, University Hospital Morafeno, Toamasina, Madagascar.

Received: 11 July 2019 Accepted: 13 December 2019

Published online: 06 January 2020

\footnotetext{
References

1. Nutten S. Atopic dermatitis: global epidemiology and risk factors. Ann Nutr Metab. 2015;66(suppl 1):8-16. https://doi.org/10.1159/000370220.

2. Taieb A. Dermatite atopique: definition, épidémiologie, histoire naturelle, gravité et scores. Ann Dermatol Venereol. 2005;132:1S35-143.

3. Margolis JS, Abuabara K, Bilker W, et al. Persistence of mild to moderate atopic dermatitis. JAMA Dermatol. 2014;150(6):593-600.

4. Kantor R, Silverberg Jl. Environmental risk factors and their role in the management of atopic dermatitis. Expert Rev Clin Immunol. 2017;13(1):15-26. https://doi.org/10.1080/1744666x.2016.1212660.

5. Rabenja Ny Lovaniaina. Dermatite atopique du nourrisson et de l'enfant. Thèse de doctorat médecine. 1999.

6. Barbarot S, Aubert H. Pathophysiology of atopic dermatitis. Ann Dermatol Venereol. 2017;144:S14-20.
} 
7. Xu F, Yan S, Li F, Cai M, Chai W, Wu M, et al. Prevalence of childhood atopic dermatitis: an urban and rural community-based study in Shanghai, China. PLoS ONE. 2012;7(5):e36174.

8. Yemaneberhan H, Flohr C, Lewis SA, Bekele Z, Parry E, Williams HC, et al. Prevalence and associated factors of atopic dermatitis symptoms in rural and urban Ethiopia. Clin Exp Allergy. 2004;34(5):779-85.

9. Kusunoki T, Asai K, Harazaki M, Korematsu S, Hosoi S. Month of birth and prevalence of atopic dermatitis in schoolchildren: dry skin in early infancy as a possible etiologic factor. J Allergy Clin Immunol. 1999;103:1148-52.

10. Cuo CL, Chen TL, Yeh CC, Chou CL, Lee WR, Lin JG, et al. Birth month and risk of atopic dermatitis: a nationwide population based study. Allergy. 2016;71:1626-31.

11. Lockett GA, Soto-Ramírez N, Ray MA, Everson TM, Xu CJ, Patil VK, et al. Association of season of birth with DNA methylation and allergic disease. Allergy. 2016;71(9):1314-24. https://doi.org/10.1111/all.12882.

12. Calov M, Alinaghi F, Hamann CR, Silverberg J, Egeberg A, Thyssen JP. The Association between season of birth and atopic dermatitis in the Northern Hemisphere: a systematic review and meta-analysis. J Allergy Clin Immunol Pract. 2019. https://doi.org/10.1016/j.jaip.2019.10.007.

13. Schäfer T. Prevention of atopic eczema. Evidence based guidelines. Hautarzt. 2005;56:232-40.

14. Taylor-Robinson DC, Williams H, Pearce A, Law C, Hope S. Do early life exposures explain why more advantaged children get eczema? findings from the UK. millenium cohort study. Br J Dermatol. 2016;174:569-78.
15. Sasaki M, Yoshida K, Adachi Y, Furukawa M, Itazawa T, Odajima H, et al. Environmental factors associated with childhood eczema: findings from a national web-based survey. Allergol Int. 2016;65(4):420-4. https://doi. org/10.1016/j.alit.2016.03.007.

16. Wen HJ, Chen PC, Chiang TL, Lin SJ, Chuang YL, Guo YL. Predicting risk for early infantile atopic dermatitis by hereditary and environmental factors. Br J Dermatol. 2009;161:1166-72.

17. Wadonda-Kabondo N, Sterne JA, Golding J, Kennedy CT, Archer CB, Dunnil MG, et al. Association of parental eczema, hayfever, and asthma with atopic dermatitis in infancy : birth cohort study. Arch Dis Childhood. 2004;89:917-21.

18. Palmer CN, Irvine AD, Terron-Kwiatkowski A, Zhao Y, Liao H, Lee SP, et al. Common loss-of-function variants of the epidermal barrier protein filaggrin are a major predisposing factor for atopic dermatitis. Nat Genet. 2006;38:441-6.

19. Rehbinder EM, Advocaat Endre KM, Lødrup Carlsen KC, Asarnoj A Stensby Bains KE, Berents TL, et al. Predicting skin barrier dysfunction and atopic dermatitis in early infancy. J Allergy Clin Immunol Pract. 2019;S2213-2198(19):30792-5. https://doi.org/10.1016/j.jaip.2019.09.014.

\section{Publisher's Note}

Springer Nature remains neutral with regard to jurisdictional claims in published maps and institutional affiliations.
Ready to submit your research? Choose BMC and benefit from:

- fast, convenient online submission

- thorough peer review by experienced researchers in your field

- rapid publication on acceptance

- support for research data, including large and complex data types

- gold Open Access which fosters wider collaboration and increased citations

- maximum visibility for your research: over 100M website views per year

At BMC, research is always in progress.

Learn more biomedcentral.com/submissions 